\title{
DEVELOPMENT OF CASE-BASED LEARNING MODEL ON BIOCHEMISTRY ONLINE LEARNING
}

\author{
Yunita Arian Sani Anwar*, Muti’ah, Syarifa Wahidah Al Idrus \\ Eka Junaidi, and Rahmawati \\ Chemistry Education Study Program, Faculty of Teacher Training and Education, University of Mataram, Indonesia \\ *Email: yunita@unram.ac.id
}

Accepted: January 05, 2022. Approved: January 09, 2022. Published: January 15, 2022

\begin{abstract}
The COVID-19 pandemic has changed the face-to-face learning process to online learning. It requires learning innovations that can make students more independent in exploring concepts. Case-based learning can be an alternative in the online learning process. This study aims to develop a case-based learning model in online biochemistry learning. This study uses six stages to modify the stages of development research. The results showed that the learning model developed consisted of five phases which became the syntax of the learning model developed, namely (1) Planning; (2) Orientation; (3) Organization; (4) Implementation; and (5) an evaluation developed following the results of the needs analysis. The developed syntax is described in model implementation guidelines and is equipped with learning tools. The validator's assessment shows that the model and device instructions have an index value of the expert agreement with a valid category. The test results on students showed that all the stages described in the guidelines could be implemented properly. Students gave a positive response to the implementation of case-based learning. Thus, case-based learning can be recommended for further learning.
\end{abstract}

Keywords: Biochemistry, online learning, case-based learning

\section{INTRODUCTION}

Reducing outside-home activities is currently the best option in suppressing the spread of the Covid19 Pandemic. The consequences of this choice make significant changes to the learning activities. The formal face-to-face learning process has now changed to learning at home. This situation makes students and lecturers have to be able to adapt certainly. Innovation in learning methods is needed to help students understand concepts and make them feel comfortable in dealing with pandemic conditions that may be faced in the long term $[1,2]$.

The closure of the campus means that the current learning process is fully implemented online. The initial implementation used WhatsApp groups more by giving assignments to students. Students experience increased boredom and stress that affect their learning outcomes $[3,4]$. During its implementation, a platform was developed in universities to make it easier for students to access material and discuss with lecturers and colleagues. However, innovation in the learning process still needs to be done, especially in increasing their intrinsic motivation, so online learning remains attractive during the pandemic $[5,6]$.

Biochemistry learning has a broad scope of material with a fairly short delivery. Nevertheless, the characteristics of the topics studied are very close to everyday life [7]. The use of the lecture method accompanied by practicum is often an option in delivering material. However, online learning which tends to apply the lecture method causes learning to be boring. In addition, the implementation of the practicum has not yet been conducted in the laboratory, so the use of the environment as a laboratory needs to be considered in the learning process [6].

Problem-based learning model (PBL) is a learning model that is often applied to increase student independence in exploring concepts. Part of PBL is Case-Based Learning (CBL) which uses cases around the community as learning resources [8]. The fields of medicine, nursing, and science often use cases in an effort to understand the concepts being studied [8-10]. The use of cases as learning resources is reported to increase students' motivation and independence in seeking the learning process [7].

Literature analysis shows that there are four stages of case-based learning that may be applied to online learning. The four stages are Planning, Organization, Implementation, and Evaluation (Table $1)$.

Table 1. Stages of Case-Based Learning [11]

\begin{tabular}{ll}
\hline $\begin{array}{l}\text { Stage 1 } \\
\text { Planning }\end{array}$ & $\begin{array}{l}\text { Planning a learning process that is } \\
\text { measurable, according to the agreed time, } \\
\text { and relevant to the topic being taught. The } \\
\text { learning planning is recommended to follow } \\
\text { Blooms' Taxonomy }\end{array}$ \\
\hline Stage 2 & $\begin{array}{l}\text { Organize students in groups through } \\
\text { Organization } \\
\text { documents and explanations regarding the } \\
\text { activities to be carried out. The } \\
\text { recommended number of students per group }\end{array}$ \\
& $\begin{array}{l}\text { is } 5 \text { people. They are assigned to read the } \\
\text { cases presented and discuss with group } \\
\text { members the questions given. }\end{array}$ \\
\hline Stage 3 & $\begin{array}{l}\text { Provide challenging questions as } \\
\text { Implementationimplications of the process that has been } \\
\text { implemented. Questions can be synthesized } \\
\text { from the information provided previously. }\end{array}$ \\
\hline Stage 4 & $\begin{array}{l}\text { Provide inquiry questions to each group to } \\
\text { be analyzed and answered together with } \\
\text { Evaluation }\end{array}$ \\
& \begin{tabular}{l} 
group members. \\
\hline
\end{tabular}
\end{tabular}

The planning stage is to design a learning process that is measurable, according to the agreed time, and relevant to the topic being taught. The 
organizational stage is organizing students in groups through documents and explanations related to the activities to be carried out. The implementation stage is to give inquiry questions to each student to be answered. The evaluation stage is carried out by asking challenging questions as the implications of the process that has been implemented [11].

The success of case-based learning depends on how effectively the case facilitates learning, integrating information with the topic to be studied and interesting information for students [12]. The cases presented can be in the form of facts or deductive information, with a narration that is not too long but all information is connected to the topic $[13,14]$. The use of questions can also be used to help students understand the given case narrative. Case descriptions are accompanied by questions, which can be in the form of multiple-choice questions or questions with short answers. It is recommended to use simple questions first. The final assessment can use questions that require contextual analysis, problem analysis, and problem solving [15].

The case-based learning reported so far has positively impacted the learning process. This learning can train students' cognitive abilities through active and student-centered learning. It is an important consideration in integrating expository knowledge that does not relate concepts to environmental conditions [14]. Cases used in education can facilitate students in understanding information and analyzing it correctly so that this tends to lead to positive perceptions of students and lecturers [16-18]. However, case-based learning has not been widely used in online learning until now. The stages described above are still limited to literature analysis, so their application in online learning needs to be investigated more deeply [11]. This study aims to develop a case-based learning model in biochemistry online learning.

\section{RESEARCH METHODS}

It is development research that follows the modification of the steps of Borg \& Gall [19], including (1) preliminary study, (2) planning, (3) product development, (4) product validation, (5) initial product revision, and (6) limited trial. The preliminary study covers online learning problems and the opportunities for using case-based learning. The target of the preliminary study is students who take Biochemistry courses. The planning stage includes product designs concerning literature studies and needs analysis results. The product design is used to develop the initial product by compiling a complete rough draft, i.e., the characteristics of the model, draft model, lesson plans, teaching materials, and assessment instruments. A rough draft is then given to three experts to evaluate the draft that has been prepared. The results of the expert assessment are used to revise the product. Limited trials were conducted to determine whether the product could be implemented in the learning process.

\section{Research Instruments}

The research instrument includes three stages, i.e., needs analysis, development, and limited trial (Table 2). The needs analysis stage uses online Biochemistry learning. The questionnaire includes open-ended questions regarding comments and suggestions on the implementation of Biochemistry learning and responses of the developed case-based learning model in improving the quality of online Biochemistry learning.

Table 2. Data Collection Instruments

\begin{tabular}{|c|c|c|}
\hline Stages & Instrument & Purpose \\
\hline \multirow[b]{2}{*}{ Needs analysis } & $\begin{array}{l}\text { Students } \\
\text { quessionnaire }\end{array}$ & $\begin{array}{l}\text { 1. Obstacles and } \\
\text { problems of }\end{array}$ \\
\hline & & $\begin{array}{l}\text { 2. Opportunities } \\
\text { for developing } \\
\text { case-based } \\
\text { learning models }\end{array}$ \\
\hline \multirow{3}{*}{ Development } & $\begin{array}{l}\text { Model } \\
\text { implementation } \\
\text { guide validation } \\
\text { sheet }\end{array}$ & $\begin{array}{l}\text { Obtain valid } \\
\text { model } \\
\text { implementation } \\
\text { guidelines }\end{array}$ \\
\hline & $\begin{array}{l}\text { Learning device } \\
\text { validation sheet }\end{array}$ & $\begin{array}{l}\text { Obtain valid } \\
\text { learning tools }\end{array}$ \\
\hline & $\begin{array}{l}\text { Evaluation tool } \\
\text { validation sheet }\end{array}$ & $\begin{array}{l}\text { Obtain a valid } \\
\text { evaluation tool }\end{array}$ \\
\hline Limited Trials & $\begin{array}{l}\text { Model } \\
\text { implementation } \\
\text { observation } \\
\text { sheet }\end{array}$ & $\begin{array}{l}\text { Get information } \\
\text { on the } \\
\text { implementation } \\
\text { of the model } \\
\text { syntax }\end{array}$ \\
\hline
\end{tabular}

The development stage instruments include a model implementation guide validation sheet, a learning tool validation sheet, and an evaluation tool validation sheet. The model implementation guide validation sheet covers aspects of syntax, social system, reaction principle, support system, instructional impact and accompaniment impact, instructional implementation instructions, and language. The tool validation sheet includes $C P L$ compliance, indicators, substance, construction, language, and objectivity. The instrument is in the form of a questionnaire with five answer choices, i.e., very poor (VP), poor (P), sufficient (S), $\operatorname{good}(\mathrm{G})$, and very good (VG).

The trial stage includes an observation sheet on the implementation of the model which includes aspects of observation in this case learning syntax, social systems, reaction principles, and support systems. Observation values include: 1) implemented, 2) partially implemented, and 3) not implemented.

\section{Data Analysis Techniques}

The data obtained from the student questionnaires were analyzed descriptively to find out the constraints of online learning and opportunities for developing a case-based learning model to overcome 
these obstacles. The results of expert validation were tabulated and calculated with the range of total scores of $1-5$, the value of the interquartile range and the standard deviation. The values obtained are interpolated in the category table (Table 3) [20,21]. The trial stage was analyzed to see what parts were implemented, partially implemented, and not implemented.

Table 3. Categories of Validator Calculation Results

\begin{tabular}{lll}
\hline No & Indicators & Category \\
\hline 1. & $\geq 80 \%$ score of $4-5$ & Very Good \\
& Interquartile $\leq 1$ \\
& Median 4-5 & \\
\hline 2. & $65 \%-70 \%$ score of 4-5 & Good \\
& Interquartile $\leq 2$ \\
& Median 4-5 \\
\hline 3. & 50\%-64\% score of 4-5 & Sufficient \\
& Interquartile $\leq 2$ \\
& Median 4-5 & \\
\hline 4. & $>50 \%$ score of 4-5 & Less \\
& Interquartile $>2$ \\
& Median $<4$ & \\
\hline
\end{tabular}

\section{RESULTS AND DISCUSSION}

The results of the preliminary study showed the learning constraints presented by students during online learning. The constraints raised can be divided into four aspects: the implementation of learning which is only theoretical and unidirectional, too many tasks, lack of access to learning, and signal constraints (Table 4).

Table 4. Obstacles in the Implementation of Online Biochemistry Learning

\begin{tabular}{lc}
\hline \multicolumn{1}{c}{ Aspects } & \% Respond \\
\hline $\begin{array}{l}\text { the implementation of } \\
\text { learning which is only } \\
\text { theoretical } \\
\text { unidirectional }\end{array}$ & 63 \\
\hline too many tasks & \\
\hline lack of access to learning & 76 \\
\hline signal constraints & 89 \\
\hline
\end{tabular}

The suggestions given indicate that learning is made more interesting by connecting the surrounding conditions. Instructions for working on assignments and materials are made more systematic and uploaded in their entirety to the $L M S$, making it easier for students to access. $93 \%$ of students need the development of a case-based learning model to improve the quality of online learning in Biochemistry.

Based on the literature and preliminary studies, a case-based learning model syntax was developed with 5 phases: planning, orientation, organization, implementation, and evaluation. The planning stage includes the stage of selecting cases that are related to the material to be delivered, designing structured assignments, developing teaching materials, and compiling the stages of teaching in the $L M S$. The orientation stage is the stimulus stage for students. The activities conducted by the lecturer at this stage explain the learning objectives and learning scenarios, explain the material by connecting to cases that exist in the community. Students can ask questions and discuss through google meet or through the discussion forum platform available on the $L M S$. The organizational stage is to organize students into several groups with 4-5 members reading the cases presented and discussing with their group members related to the questions given. The implementation stage is the stage of conveying the results of group discussions and answering challenging questions related to the entire discussion conducted. The evaluation stage gives students the opportunity to summarize the concepts they have learned in a shortwritten form with a predetermined format. The overall syntax is shown in Figure 1.

The case used in this study is the case of the COVID-19 virus. The topic of viruses can be related to the structure and physicochemical properties of protein macromolecules, carbohydrates, nucleic acids, and fats. The viral life cycle can be related to the metabolism of the four macromolecules previously discussed. Technically, structural assignments are given through articles related to Covid-19 cases and questions can relate to the structure of the virus that composes the virus related to proteins, carbohydrates, nucleic acids, and fats. Articles related to health protocols such as washing hands with soap and the use of disinfectants are related to the physical and chemical properties of lipids as macromolecules that make up cell capsids. The spread of the virus can be related to the viral life cycle which is connected with a central dogma involving nucleic acids and proteins.

Each group gets a different case through the articles given. Students are asked to discuss to find keywords related to Biochemistry material. Furthermore, with group members discuss related to the questions given.

Lecture materials such as teaching materials, articles assigned to each group, a list of questions as discussion material, instructions for working on assignments, formats for compiling a summary, and a schedule for submitting discussion results are uploaded to the $L M S$ in order that it can be easily accessed by students. The discussion forum platform is activated, so students can discuss with the group members and can ask the lecturers things that they have not understood.

Feedback is given by the lecturer at the time of delivering the results of the discussion and the responses given by other group members. Evaluation is in the form of compiling a summary related to the results of the discussion in a predetermined format. The final assessment is in the form of expressing opinions (oral skills), summary writing skills and the ability to answer questions. 


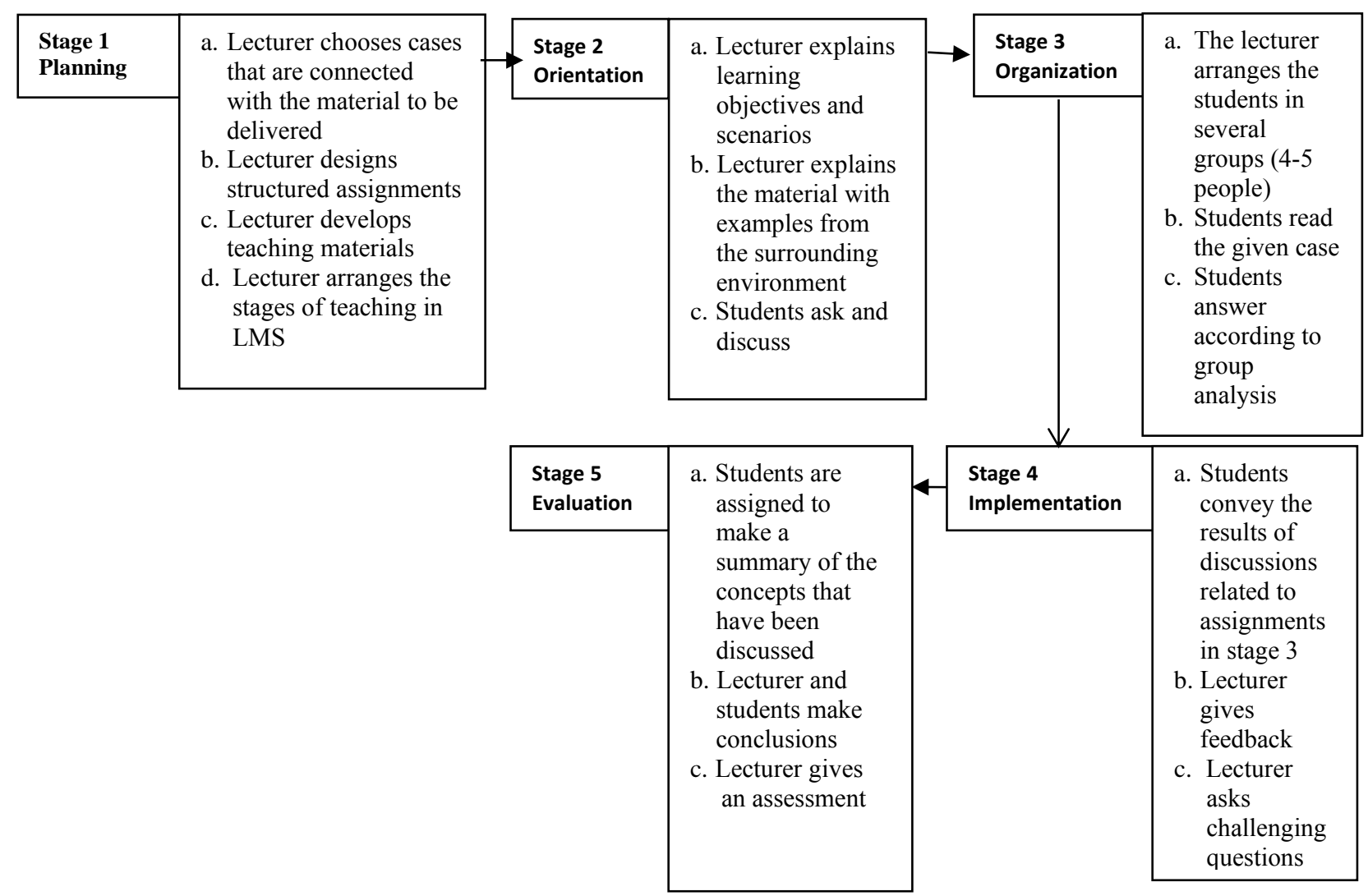

Figure 1. Syntax of Case-Based Learning Models in Online Biochemistry Lectures

The results of the assessment by the validator regarding the guidelines for the use of the case-based learning model showed that the average value of all aspects has very good and good category (Table 5). Suggestions given by the validator regarding the guidelines include (1) the sequence of activities needs to consider time considering that learning is conducted online, (2) the relationship between lecturers and students needs to be studied related to the limitations of interaction in online learning, (3) Assessment of student activities when responding is also necessary to become an assessment, and (4) the maximum duration of time required should be added to the implementation manual.

Table 5. The results of the assessment of the model use

\begin{tabular}{ll}
\hline \multicolumn{1}{c}{ Aspects } & \multicolumn{1}{c}{ Category } \\
\hline Syntax & Good \\
Social system & Very Good \\
Reaction principle & Good \\
$\begin{array}{l}\text { Support system } \\
\text { Instructional impact and }\end{array}$ & Good \\
$\begin{array}{l}\text { accompaniment } \\
\text { Indicators of learning } \\
\text { implementation } \\
\text { language }\end{array}$ & \\
\hline
\end{tabular}

Tabel 6. Hasil penilaian perangkat dan evaluasi

\begin{tabular}{lc}
\hline \multicolumn{1}{c}{ Aspects } & Category \\
\hline CPL suitability & Good \\
Indicator & Good \\
Substance & Good \\
Construction & Good \\
Language & Good \\
Objectivity & Good \\
\hline
\end{tabular}

The results of the validator's assessment related to learning tools and evaluation tools showed that the average value of all aspects has a good category (Table 6). The suggestions given include (1) prioritizing skill development considering that learning is conducted online, (2) teaching materials need to be reproduced with interesting illustrations, and (3) the rubric for assessing learning activities recorded in the $L M S$ needs to be added to the rubric.

The results of model testing show that all stages of the syntax can be conducted properly. However, the use of the discussion forum platform has not optimal, so it is necessary to socialize to students the role of the platform to help them if having difficulties. The results of the observations showed that (1) all students played an active role in the discussions, (2) all students do the instructions for working on assignments according to the given 
design, (3) all students help each other if having difficulties, and (4) all students submitted assignments on time. The part that is still lacking is the use of a discussion forum platform making the summaries did not meet the rules of scientific writing, and signal constrain making students unable to follow the learning process properly.

Student responses during the online learning process of Biochemistry with a case-based model indicate that most students feel interested and challenged in attending lectures. Most students recommend a similar learning process to make it easier for them to understand the relationship between concepts and cases that occur in their environment. Table 7 shows the percentage of student responses during lectures.

Table 7. Student response to the implementation of case-based learning model

\begin{tabular}{lccccc}
\hline \multicolumn{1}{c}{ Questions } & $\begin{array}{c}\mathrm{VG} \\
(\%)\end{array}$ & $\begin{array}{c}\mathrm{G} \\
(\%)\end{array}$ & $\begin{array}{c}\mathrm{S} \\
(\%)\end{array}$ & $\begin{array}{c}\mathrm{P} \\
(\%)\end{array}$ & $\begin{array}{c}\mathrm{VP} \\
(\%)\end{array}$ \\
\hline $\begin{array}{l}\text { Interest in } \\
\text { attending lectures }\end{array}$ & 40,74 & 25,93 & 33,33 & 0 & 0 \\
$\begin{array}{l}\text { Understanding of } \\
\text { Biochemistry } \\
\text { material }\end{array}$ & 37,04 & 29,64 & 18,52 & 0 & 0 \\
$\begin{array}{l}\text { The connection of } \\
\text { the cases to the }\end{array}$ & 55,56 & 33,33 & 11,11 & 0 & 0 \\
material presented \\
$\begin{array}{l}\text { Feedback given by } \\
\text { the lecturer }\end{array}$ & 59,26 & 40,74 & 0 & 0 & 0 \\
\hline
\end{tabular}

The comments that are mostly given by students are case-based uses increase their knowledge and provide them new knowledge. In addition, students commented that use cases made Biochemistry material relevant to their lives. So far, they think that Biochemistry is more about material that are difficult to understand. In addition, case-based learning makes their assignments not much to do and can be summed up in one task. The difficulty of discussing with friends because in online conditions causes the discussion stage to be less.

The advice given by students is to train more in writing because they find it difficult to make it. In addition, lecturers are asked to explain not too quickly so that it is easier to understand the material presented and understanding student conditions related to signal interference during lectures.

Student learning outcomes using questions containing cases showed an average score of 71.72; the average writing is 70 ; and student graduation is $96.3 \%$.

The implementation of case-based learning in this study has several advantages. Students become connected between the concepts and the cases given and feel that the concepts of Biochemistry are useful for their lives. The results of previous studies have reported that Biochemistry learning so far involves more concepts and is not relevant to the lives of students [22,23]. Many concepts cause students feel limited in developing their arguments. Through cases, students can argue related to the cases they study both according to their perspectives and the results of discussions that have been conducted [24,25].

The disadvantage of case-based learning in online Biochemistry learning is that it requires thorough prior knowledge in explaining concepts and connecting with the cases used. In addition, the selection of relevant cases and questions as a guide in understanding the material need to be well prepared. The discussion stage becomes less meaningful because the online implementation limits student interaction with other students. One of the factors that influence the success of online learning is the interaction between students and content, students with students, and students with instructors [26]. Student interaction with content is the dominant factor that often exists in the online learning process [27]. The three factors should ideally contribute to the success of learning, but student-student interaction is reported to have a major contribution to online learning [28].

Related to the interaction of students who are still lacking in this learning process, it is recommended to be able to activate the discussion forum platform in the $L M S$. Until now, the platform has not been fully activated by students, even though the platform can connect students and lecturers. This is possible as the cause of the discussion process did not go as well as desired.

\section{CONCLUSION}

This research has developed a case-based learning model for online learning of Biochemistry. Five stages become the syntax of the learning model developed: (1) Planning; (2) Orientation; (3) Organization; (4) Implementation; and (5) Evaluation; clearly described in the guidelines for implementing the model. The device was developed using cases experienced by students, i.e., Covid-19 Pandemic cases ranging from virus composition to activity habits by paying attention to health protocols and their relationship to the virus life cycle. The results of the validator's assessment indicate that the guidelines for implementing the model and learning tools have good assessment results so that in terms of content, they have good validity and reliability. Student responses indicate that the learning model provides students with new knowledge so that it is recommended to be applied to the next lesson.

\section{REFERENCES}

[1] Viner, R. M., S. J. Russell, H. Croker, J. Packer, J. Ward, C. Stansfield, O. Mytton, C. Bonell, R. Booy. (2020). School closure and management practices during corona virus outbreaks including COVID-19: a rapid systematic review. Lancet Child Adolesc Health, 4, 397-404.

[2] Erduran, S. (2020). Science education in the era of a pandemic: how can history, philosophy and sociology of science contribute to education for 
understanding and solving the covid-19 crisis? Science \& Education, 29, 233-235.

[3] Liberman-Martin A.L, \& Ogba, O. M. (2020). Midsemester transition to remote instruction in a flipped college-level organic chemistry course. J Chem Educ, 97, 3188-3193.

[4] Cao, W., Fang, Z., Hou, G., Han, M., Xu, X., Xong, J., et al. (2020). The psychological impact of the COVID-19 epidemic on college students in China. Psychiatry Res, 287, 112934.

[5] Lin, Y., McKeachie, W. \& Kim, Y.C. (2003). College student intrinsic and/or extrinsic motivation and learning. Learn Indiv Differ, 13, 251-258.

[6] Hsu, J.L. \& Rowland-Goldsmith, M. (2020). Student perceptions of an inquirybased molecular biology lecture and lab following a mid-semester transition to online teaching. Biochem Mol Biol Educ, 1-11.

[7] Varghese, J., Faith, M., \& Jacob, M. (2012). Impact of e-resources on learning in biochemistry: first-year medical students perceptions. BMC Medical Education, 12(21), $1-9$.

[8] Kaddoura, M.A. (2011). Critical thinking skills of nursing students in lecture-based teaching and case-based learning. International Journal for the Scholarship of Teaching and Learning, 5 (2), 1-18.

[9] Chan, W. P., C.Y. Hsu, C. Y. Hong. (2008). Innovative "Case-Based Integrated Teaching" in an undergraduate medical curriculum: development and teachers' and students' responses. Annals of the Academy of Medicine, Singapore 37, (11), 952-956.

[10] Dietrich, J.E., N. K. De Silva, A. E. Young. (2010). Reliability study for pediatric and adolescent gynecology case-based learning in resident education. Journal of Pediatric and Adolescent Gynecology 23 (2), 102-106.

[11] Thibaut, D., \& Schroeder, K.T. (2020). A casebased learning approach to online biochemistry labs during COVID-19. Biochem Mol Biol Educ., 48, 484-485.

[12] Millard, D.,Howard, Y,Gilbert L.,\& Wills, G.(2009). Co-planning and Co-deployment Methodologies for Innovative m-Learning Systems. School of Electronics and Computer Science University of Southampton.

[13] Chester, V. (2011) Using clinical gait case studies to enhance learning in biomechanics. Biosci. Educ. 17, 51-84.

[14] Kulak, V., \& Newton, G. (2014). A guide to using case-based learning in biochemistry education. Biochem Mol Biol Educ., 42(6),457473.

[15] Villafañe, S. M., Bailey, C. P., Loerstcher, J., Minderhout, V., and Lewis, J. E. (2011). Development and analysis of an instrument to assess student understanding of foundational concepts before Biochemistry coursework. Biochem. Mol. Biol. Educ., 39, 102- 109.

[16] Kulak, V., Newton, G., \& Sharma, R. (2017). Does the use of case-based learning impact the retention of key concepts in undergraduate biochemistry? Int J High Educ., 6(2):110-120.

[17] Patil, V.S., Tiwale, S.M., Iyer, P., Venugopal, N.T., Kulkarni, C.S., \& Kumbhar, A. (2017). A study of perception of first year MBBS students on case-based learning in biochemistry as a method to improve analytical thinking. Nat $J$ Integr Res Med. 8(5), 67-70.

[18] Suhasini, P., Joshi, K.P., Swaroopachary, R.S., Yamini, D., \& Sarma, D.V.H.S. (2017). An effective approach in learning clinical biochemistry-Case based learning. J Educ Technol Health Sci. 4(2), 62-64.

[19] Borg, W.R., \& Gall, M.D. (1989). Educational research: an introduction ( $5^{\text {th }} \mathrm{ed}$.). New York: Longman.

[20] Giannarou, L., \& Zervas, E. (2014). Using delphi technique to build consensus in practice. International Journal of Business Science and Applied Management, 9(2), 65-82.

[21] Hackett, S., Masson, H., \& Philips, S. (2006). Exploring consensus in practice with youth who are sexually abusive: findings from a delphi study of practitioner views in the United Kingdom and the Republic of Ireland. Child Maltreatment, 11(2), 146-156.

[22] Afshar, M., \& Han, Z. (2014). Teaching and learning medical biochemistry: perspectives from a student and an educator. Medical Science Educator, 24(3), 339-341.

[23] Fulton, T.B., Ronner, P., \& Lindsley, J.E. (2012). Medical biochemistry in the era of competencies: is it time for Krebs cycle to go? Medical Science Educator, 22(1), 29-32.

[24] Borrell, Y.J., A. M. Muñoz-Colmenero, E. Dopico, L. Miralles, E. Garcia-Vazquez. (2016). Food control and a citizen science approach for improving teaching of genetics in universities. Biochem Mol Biol Educ. 44, 450-462.

[25] Fernández, S., L. J. Rodríguez-Muñiz , J. Molina, L. Muñiz-Rodríguez, J. Jiménez, E. García-Vázquez, Y. J. Borrell. (2020). Lab experience with seafood control at the undergraduate level: Cephalopods as a case study. Biochem. Mol. Biol. Educ. 48 (3), 236246.

[26] Castro, M.D.B., \& Tumibay, G.M.A. (2019). A literature review: efficacy of line learning courses for higher education institution using meta-analysis. Educ Inf Technol.

[27] Ali, M., Yaacob, R.A.I.B.R., Endut, M.N.A.A.B., \& Langove, N.U. (2017). Strengthening the academic usage of social media: An exploratory study. Journal of King Saud University-Computer and Information Sciences, 29(4), 553-561. 
J. Pijar MIPA, Vol. 17 No.1, January 2022: 16-22

[28] Hussin, W.N.T., Harun, J., \& Shukor, N.A. (2019). Online interaction in social learning environment towards critical thinking skill: a framework. JOTSE, 9(1), 4-12. 